a family of Jewish origin, who fled from Germany in the face of Hitler's accession to power in 1933. McGillicuddy's attention is placed on the emotional traumas suffered by the nineyear-old Anne and her family, caused by the crossing of linguistic, national and cultural boundaries during her childhood and youth.

The fourth topic is "Gender politics". Marian Thérèse Keyes explores the role played by the paratext (as created by the publisher or the author) in ideologically preparing the reader for the encounter with the text. For this purpose, she analyses the works of Anne Marie Fielding Hall (1800-1881), more precisely her three frontispiece portraits and paratextual elements of The Juvenile Forget-Me-Not (1829-1837).

Brigitte Le Juez examines the film adaptation of the story about Bluebeard produced by French director Catherine Breillat in 2009 under the title Barbe Bleue. Le Juez finds reasons for the appearance of a host of interpretations, adaptations, rewritings of this story in diverse cultural and historical contexts in the fascination with its realistic basic motif: "the husband as a serial abuser and killer of his young bride(s)" (158), that is, in the central theme of psychological and sexual abuse.

Marion Rana describes the presentation of rape and sexual violence in contemporary young adult novels, as well as numerous myths that make up the commonplaces of contemporary culture, employed to justify rape or diminish its criminal nature.

The edited collection of essays Politics and Ideology in Children's Literature opens up a whole range of thought-provoking perspectives on Irish children's literature, which is insufficiently researched. At the same time, it offers insight into Irish research of children's literature (where we can look for parallels with the situation in Croatian research). In doing so, this collection of essays also brings Ireland closer to us. There are many similarities between Ireland and Croatia. Undoubtedly, when such a large number of Croats are choosing Ireland as a country where they hope to achieve their ambitions, there must be a certain sense of affinity, surpassing pure economic interests. Perhaps this fact also makes it difficult for us to resist the temptation to look for parallel experiences and parallel practices, in particular with regard to the themes of politics and ideology, evidently a delicate topic in both countries. Still, however difficult it might be for us in Croatia to resist such interpretations, we should note that we are also facing a very different culture, whose experiences can be really precious.

Berislav Majhut (translated by Snježana Veselica-Majhut)

\title{
History Revaluated
}

Helen A. Fairlie. 2014. Revaluing British Boys' Story Papers, 1918-1939. London: Palgrave Macmillan. 210 pp. ISBN 978-1-137-29305-3

DOI: 10.21066/carcl.libri.2016-05(02).0010

The book Revaluing British Boys 'Story Papers, 1918-1939 presents a bright example of the successful application of various theoretical approaches in a case study of children's literature. Helen A. Fairlie focuses on revaluation, as the title says, of boys' story papers published in Britain in the period from 1918 to 1939. As Fairlie emphasises, this period of British children's literature was often interpreted as a decline in the quality of children's 
books which came after the "golden", late Victorian years and today is generally considered as unexciting and tasteless, "an ocean of terrible trash" (18). To overcome this perspective, Fairlie recognises this period as a cultural phenomenon and tries to explain it without attributing any marks of value to it. She observes story papers as cultural products consumed by child consumers and shaped at the same time by the cultural environment (cinema or comics) and its readership (questioning children's preferences).

In her research, Fairlie combines textual theoretical analysis and historical investigation. Through six chapters she positions story paper narratives in a socio-cultural context with special attention to power relations between producers and consumers, and analyses it in the context of popular culture (discovering analogies and influences between story paper narratives and cinema serials). Furthermore, she interprets the texts according to the ideological messages produced in moral codes, school world images and hero figures in stories, school world images and hero figures, and uses story papers as cultural artefacts situated in an economic and cultural field of production, while also taking into account their paratextual elements.

In order to be able to make such a broad cultural analysis, the subject of the research had to be narrowed as far as possible. This is why Fairlie focuses on just two representative story papers: The Magnet (1908-1940) and The Hotspur (1933-1959), both published in the period between the two world wars, aimed at the same audience (boys) of approximately the same age (12-15) and exploiting the same genre (school stories).

Fairlie bases her research mainly on the theories of new historicism and cultural materialism which she applies to the field of children's literature. Beside contextualising the phenomenon in a historical setting (contemporary practices of publishing for children, changes in the educational system) and explaining it from the perspective of cultural production (the rise of the cinema and other mass media), she employs documentary resources, such as surveys and memories of childhood reading experiences from that time, to describe the formation of a new consumer: the autonomous child reader who chooses his leisure reading matter by himself.

Reader-response theory serves as a frame for analysis of the ideology transferred through story papers. Fairlie concludes that story paper producers/authors were both "reconstructing and reinforcing the dominant social character" (66) after the First World War in order to regain the stability of pre-war mythologies. Although the analysis of identified conservative values depicted through the moral code, schooling system, and hero characteristics presented in the two narratives in focus is welcome, it would be also useful to set these values in a broader context in order to see their role and strength in comparison to other lines of power in literature which competed for the child's attention. Furthermore, what would be the final goal and impact of these messages directed at working- and lowermiddle-class children? It is nicely shown how story papers influenced the development of the school story genre, but it would also be interesting to see the position of the genre and the whole phenomenon in the wider context of children's literature of that time.

The last two chapters show the full potential of the cultural theory framework for research in children's literature. By recognising the child as a consumer, not just as a reader, Fairlie approaches children's everyday life which was flooded by the variety of stories 
presented in different media (newspapers, cinema, magazines, comics). The author shows how cinema affected the story paper narrative (use of cliff-hangers) and style (cinematic speed in the succession of action events) and ultimately led to its final decline. Fairlie sees this field of entertainment production for children as a constant competition in which story papers eventually lose the battle (story papers disappeared by the 1960s) (187) against the strong appeal of visual (cinema) and multimodal (comics) storytelling.

The theoretical approaches of new historicism and cultural materialism make it possible for this study to view the story paper genre in a completely new way. For the study of children's literature, this research is valuable from several viewpoints: it shows how these entertaining and, for children, affordable narratives excluded adults from the authortext-reader communication and turned children into consumers (of different kinds of goods as well), and how other mass media brought a change of style and narrative construction to the school story genre (I assume this influence may have a much broader application). Finally, it tries to construct an image of childhood leisure experience in reading story papers in the period between the two world wars. In this way, this study can certainly contribute to developing a new perspective on the history of children's literature.

Sanja Lovrić Kralj

\section{SuperDahl: Literature, Criticism and Paratext}

Laura Viñas Valle. 2016. De-constructing Dahl. Cambridge: Cambridge Scholars Publishing. 191 pp. ISBN: 978-1-4438-8258-3

DOI: 10.21066/carcl.libri.2016-05(02).0011

The book De-constructing Dahl by Laura Viñas Valle, published by Cambridge Scholars Publishing in 2016, is an academic study of the children's literary works of Roald Dahl from the point of view of socio-cultural constructivist theory, and the first singleauthored monograph on Roald Dahl since 1994. The long list of sources, acknowledgments and references is proof that the author spent a substantial amount of time immersed in research on this famous, highly complex and controversial author in an attempt to subject Dahl "to a de-constructing process which has entailed analysing the assumptions that underpin claims made about 'children', 'childhood' and 'children's literature'” (165).

Accordingly, the book is divided into three chapters which landmark the authorial process of de-construction. The author claims that despite Dahl's popularity, there is not much scholarly work available on his writing and lists three existing book-length studies: Alan Warren's Roald Dahl: From the Gremlins to the Chocolate Factory (1988), Mark I. West's Roald Dahl (1992), and the essay collection Roald Dahl (2012) edited by Catherine Butler and Ann Alston. These are outnumbered by several biographies on Dahl, written by Chris Powling (1985), Jeremy Treglown (1994), Jennet Conant (2008), Donald Sturrock (2010) and Michael Rosen (2012). The book De-constructing Dahl is therefore an attempt to review, complement and contextualise the exploration of Dahl from a multitude of perspectives.

In the first chapter, "De-constructing Dahl through Criticism", Viñas Valle provides a thorough overview of the criticism and reception of Dahl's work within the context of a variety of literary and cultural theories. The overview addresses text-based approaches to 